$\begin{array}{llllllll}\text { Studia } & \text { z } & \text { Dziejów } & \text { Rosji } & \text { i Europy } & \text { Środkowo-Wschodniej } & \text { - LII-SI(3) } \\ \text { A } & \text { R } & \text { T } & \text { I } & \text { C } & \text { L } & \text { E } & \text { S }\end{array}$

Andrzej Nowak

Tadeusz Manteuffel Institute of History, Polish Academy of Sciences

\title{
Eastern Europe and the British Imperial Imagination, 1914-1919
}

Zarys treści: Pierwsza wojna światowa wymusiła na elitach Europy Zachodniej potrzebę określenia, czym ma być Europa Wschodnia, jak wyglądać będzie nowy porządek polityczny po zakończeniu wielkiej wojny, czy da się utrzymać równowagę między Rosją a Niemcami oraz co zrobić z coraz większymi ambicjami Rosji sowieckiej przywrócenia kontroli nad ziemiami byłego Imperium Rosyjskiego. Niniejszy tekst dotyczy wizji Europy Wschodniej wśród brytyjskich elit politycznych od memoriału Arthura Balfoura z 1916 r. do koncepcji tej części Europy stworzonej w kręgu premiera Davida Lloyda George’a w 1920 r. oraz analiz Halforda Mackindera, ojca brytyjskiej geopolityki.

Outline of contents: During the Great War elites of Western Europe were forced to decide on their perception of Eastern Europe, on a new political order after the end of the war, and to think out how to keep the balance between Russia and Germany and what to do with increasing ambitions of Soviet Russia to regain control over the territories of the former Russian Empire. This text attempts to re-create the specific frame of mind of early twentieth-century British political elites which influenced their perception of Eastern European developments from Arthur Balfour's memorial in 1916 to Eastern Europe's concepts by Prime Minister David Lloyd George in 1920 and analyses of Sir Halford Mackinder, the father of British geopolitics.

Słowa kluczowe: Polska, Europa Wschodnia, sprawa polska w czasie I wojny światowej, Wielka Brytania w czasie I wojny światowej, brytyjska polityka zagraniczna, David Lloyd George, Arthur Balfour, Halford Mackinder

Keywords: Poland, Eastern Europe, Polish cause during World War I, Great Britain during World War I, British foreign policy, David Lloyd George, Arthur Balfour, Halford Mackinder

"British public opinion was ill-informed about European geopolitical realities and influenced by assumptions and illusions drawn from Britain's own unique history. Nor was the British public ever much interested in Eastern Europe, whose affairs 
were assumed to be of little consequence for British security". ${ }^{1}$ This observation is fair as far as it goes. But it is not enough, if we want to re-create the specific frame of mind of early twentieth-century British political elites which influenced their perception of Eastern European developments in the turbulent years of the Great War and its aftermath.

Maybe not just one frame, nor just one mind, and maybe not just then. If one wishes to grasp the issue of "mental maps" of imperial elites and to understand its - possibly only theoretical - paradoxes, it is worth consulting a model constructed by a Norwegian political scientist, Ola Tunander. Analysing the geopolitics of the post-Cold War situation in Europe, he pointed to two competing structures of political imagination. ${ }^{2}$ One is based on a hierarchical vision of the world as a continuum stretching from the Universe (Order, Civilization) to Chaos (Barbaria). This model, reminiscent of Enlightenment thinking, assumes there is only one order which is of a universal nature and leaves no room for any pluralism in its civilization. There is no room for dialogue, only instructions given by the advanced to the underdeveloped. This is the model of the West (and the Rest). Within the system of Universe-Chaos, stresses Tunander, traditional disputes about territories and domination in space lose their importance. New ideas, technologies, capital transactions, and decision-making centres tend to become concentrated. How close they are to the centre of the new Order is the most important issue. Peripheries, crucial for the size of empires, may turn into a burden. The imperial centre may even cut off some peripheries, parts of its "sphere of obligation", which drag it towards Chaos.

The world of imperial imagination includes a second model of perceiving political and cultural reality, one much more deeply rooted in history. This is the "Schmittian" concept based on a fundamental differentiation between Friends and Foes. Various civilizational models focused around empires (or helping empires to crystallize) compete with one another. Their rivalry extends also to space. Loss of a periphery immediately strengthens the other competitor. It is not about expanding the "Order" - it is about the approach of the "Enemy". This is a zero-sum game. Exercising control over "strategic" points on the map of rivalry with other players is a clear imperative, regardless of the price the imperial centre would have to pay for it in economic terms, in order to prevent strategically important parts of the Empire from being controlled by rivals.

When confronted with attempts to put the world scene in order, imperial thought searches for answers in its own imperial tradition. It does so by combining its "Enlightenment" model, where the Empire formed a part of the common ground

\footnotetext{
${ }^{1}$ D. Lieven, Towards the Flame. Empire, War and the End of Tsarist Russia, London, 2015, p. 300.

2 O. Tunander, "Post-Cold War Europe: A Synthesis of a Bipolar Friend-Foe Structure and a Hierarchic Cosmos-Chaos Structure?", in: Geopolitics in Post-Wall Europe, eds. O. Tunander, P. Baev and V.I. Einagel, London, 1997, pp. 17-44. See my development of this model in: A. Nowak, History and Geopolitics: A Contest for Eastern Europe, Warsaw, 2008, pp. 201-233.
} 
of one Civilization and Order and justified its mission of expansion and exercising control over huge areas from Central Europe to the Pacific Ocean with the model of "warring civilizations", that is by combining the "Universe-Chaos" model with the "Enemy-Friend" one. Or it can stay with one of these models and set of answers it gives for a particular geopolitical challenge. Selecting the right answer proved to be the most difficult with regard to a Europe where the Centre meets the East, referred to by some people as Central, by others as Eastern or Central and Eastern Europe. This cross-border region between "the West", the axis of the modern "Order", its German self-proclaimed representatives, and its eastern, Euro-Asiatic, Russian imperial neighbour, principal rivals in the "Enemy-Friend" model - was actually the least known and the least interesting from the British point of view.

In 1914 the only imagined British interest in Eastern Europe was stability. Herbert Asquith's liberal government entered the Great War with no intention of redrawing the political map of continental Europe. The British statesmen neither intended to break any empires nor to "make" any nations there. Quite the contrary, they wanted to save the Continent from any geopolitical revolution. The three Eastern European empires - Romanov Russia, Habsburg Austria-Hungary, and the Hohenzollern German Reich - were considered as pillars of the order that were to be kept, at least in the vast territories between Germany proper, Russia proper, and the Balkans.

"Germany proper" and "Russia proper" do not comprise, in the British political imagination of 1914, any ethnographic entities, but the "just" and "proper" places accorded to two co-members of the "imperial concert" on the London elite's mental maps. Russia had a vast potential to become "improper" in Asia, where her expansion collided with the interests of the British Empire: from Constantinople and the Straits, through the Caucasus, Persia, Afghanistan, India, Tibet, all the way to China. Germany also had a potential to become "improper", and to form a perceived danger in the British political elites' eyes. This was firstly because of Berlin's bid to stretch out, through its domination over Vienna, as far as to Constantinople, to Turkey, to the Middle East, close to the centre of the British Empire. Secondly, it was because of Berlin's naval ambitions. Finally, a fear of a final German victory over France and the consolidation of Berlin's grip over the western half of the Continent was the straw that broke the post-Victorian camel's back. The balance of power in Europe was in danger.

British imperial elites were as ready to use Russia "proper" to balance "improper" Germany, as they had been ready to use Germany to balance Russia before and - as we shall see - after the 1914 crisis. But the balance itself between Germany and Russia in Eastern Europe was believed in London to be fine. So it seemed obvious to restore that balance after German "impropriety" elsewhere (in Belgium) had been castigated. Russia and Germany (with Austria as an adjunct to Berlin) were both seen in London as necessary, principal, and not infrequently even as the only partners in keeping a stable order between the Baltic, the Danube, and the Black Sea. 
Which one of them should be given a larger share of the territories in-between was a matter that affected more than just the Eastern European balance of power. So - enemies sometimes, but in the longer run important partners in sharing with the British, the French, and the Americans their common task of playing Atlas: to keep sunny skies over the world against all possible forces of disorder - this could be the safest description of the place of Russia and Germany on the mental map of the imperial elites in London before the outbreak of the Great War.

A principle of nationality or, rather, the very existence of political ambitions and projects of nationalities other than Russians and Germans in Eastern Europe could belong to a list of possible forces of disorder to be tamed, rather than to a list of questions to be resolved with the help of the British Empire. The moral instincts of the liberal majority of Asquith's government were expressed in this geographical direction in their dislike of Tsarism and hopes for its evolutionary dissolution by the rays of general progress - a dissolution brought about by the efforts of the Russian people. Nothing else was imagined.

British statesmen were forced to exercise their geographical imagination by the sheer magnitude of the consequences of the decision to enter the war against Germany. As it happened, war meant entering Eastern Europe, at least since Russia had proven to be unable to control that region by herself, and a spectre of a German Mitteleuropa began to materialize. This moment came at the end of 1916, exactly when a new coalition government was formed in London, with David Lloyd George as the new prime minister. Even before he would take the Foreign Office in the new government, Arthur Balfour, by then the most senior member of the British imperial establishment, presented a memorandum entitled "The Peace Settlement in Europe", signed on 4 October 1916, and prepared at the request of the prime minister. The memorandum offers the most instructive insight into the place which Eastern Europe, and its crucial political problem - Poland - occupied in the British imperial mind burdened with the Great War.

Balfour, who had himself been prime minister between 1902 and 1905, when he had been the architect of the 1904 Entente cordiale with France, had been already present at the creation of a peace settlement along with Lord Salisbury and Disraeli - as far back as at the Berlin Congress in 1878. He knew that the principal object of a war is the attainment of a durable peace. The logic of the Friend-Foe model operated in his concept of a post-Great War peace against Germany and Austria. So Balfour suggested that "the area from which the Central Powers can draw the men and money required for a policy of aggression" 3 should be diminished. As a consequence, ethnographically Polish territories of Germany and Austria should be detached from the inimical powers. But where should they go? The Cosmos-Chaos model was even more important to Balfour - and

\footnotetext{
3 A. Balfour, The Peace Settlement in Europe, quoted after: D. Lloyd George, War Memoirs, London, vol. 1 [1933], p. 524.
} 
from this perspective "what we rather vaguely call 'the principle of nationality" was considered both a chance and a danger. At least when applied to a nation (or any group of nations) between the two established (or re-established, as was hoped, after the War) pillars of Eastern European order - that is Germany and Russia.

Balfour introduced "the Polish question" in his October 1916 memorandum, beginning with "a purely British point of view", that is with the Friend-Foe, "realistic" perspective. "The Foe" at that moment was Germany, as well as its ally Austria-Hungary. So in order to make the Central Powers weaker and less capable of any further aggression, Balfour suggested that it would have been necessary to detach from them "as much of Austrian and German Poland as possible", and to unite these territories with "Russian Poland", that is with the westernmost part of the Tsarist share of the prepartitioned Polish-Lithuanian Commonwealth. However, Lord Arthur added an important caveat to this suggestion: "But I should not like to see the old Kingdom of Poland restored. I should fear that the new Poland would suffer from the diseases through which the old Poland perished; that it would be a theatre of perpetual intrigues between Germany and Russia; and that its existence, so far from promoting the cause of European peace, would be a perpetual occasion of European strife. Moreover, even if such Poland were capable of playing the part of an efficient buffer State (which I doubt), I am not sure that a buffer State between Germany and Russia would be any advantage to Western Europe. If Germany were relieved of all fear of pressure from Russia, and were at liberty to turn her whole strength towards developing her western ambitions, France and Britain might be the sufferers, and I am by any means confident that cutting off Russia from her western neighbours might not divert her interests towards the Far East to an extent which Britain statesmen could not view without some misgivings. The more Russia is made a European rather than an Asiatic Power, the better for everybody". ${ }^{4}$

Balfour introduces first a possible role for "lesser" Eastern European nationalities (such as Poles) as potentially useful instruments against contemporary enemies: the Central Powers. He reminds us quickly, however, that from a more universal point of view (that of "Western Europe", and "the cause of European peace", finally - "for everybody") it is better not to introduce any new political entity between Germany and Russia. Maybe the Poles want to have their independent state, but it would be better "for everybody", and for the European balance of power, surely, if they did not. Balfour presents his belief (rather typical to a majority, probably, of the late Victorian political elite - both in its conservative and liberal branches) that he knows better what is good "for everybody". ${ }^{5}$ And, moreover, not everyone

${ }^{4}$ Ibid., pp. 525-526.

${ }^{5}$ See an interesting analysis of this phenomenon: U. Singh Mehta, Liberalism and Empire. A Study in Nineteenth-Century British Liberal Thought, Chicago (IL), 1999. 
else knows that. Especially other peoples - those who could endanger peace and balance between empires, the "real" players of international politics - are not able to speak for themselves. Moreover, they should not have this possibility. They always have some "old, bad habits", or could form a "theatre of perpetual intrigues", which is better to avoid. They do not represent themselves but only the danger of Chaos. Order restored is an order between known empires. Balfour had prepared a general scheme of such an order before the war, in his letter (from 1909) to the president of the United States, Theodore Roosevelt. In this, he presented his rather gloomy vision of Western civilization's decadence and its possible end, inundated by alien, non-Western cultures. But he also depicted the cure or rather the means to delay that process. It had a form of an Anglo-Saxon Confederation, that is, a close alliance between the United States and the British Empire, as the basis of the world order. It should be helped in other parts of the globe with other confederations (empires): a Russian, a German, a "Latin" (with France, Spain, and Italy in its core), and an "Asiatic" one - Japanese or Chinese. These are forces of Order - necessary to stop oncoming Chaos. ${ }^{6}$

The fact that imperial Russia collapsed four months after Balfour's October 1916 memorandum and the Bolsheviks took the power in Petrograd a year later, complicated the restoration of that sort of order, at least in Russia and Eastern Europe. The Central Powers, still the enemies of the British empire in the war, could not have been counted as partners for London (even less so for Paris), at least at that moment. Poles, and other nations from the region between Germany and Russia, found their chance to (re)enter the political map. I do not intend to enumerate here the list of official declarations of the British government which followed in 1917 and 1918, along with the famous "Fourteen points" of the newly associated power's leader, President Woodrow Wilson, dealing with the rights of nations and prospects of new states in Eastern Europe. ${ }^{7}$ How were these prospects and pledges stemming from an acute, but temporary stage of a Friend-Foe situation (separating London from both Berlin and Petersburg/Petrograd - finally "Red" Moscow, former traditional guarantors of stability in "faraway" countries of Eastern and Central Europe), to be reconciled with a vision of a stable post-war Order, taming once again a tide of Chaos? This was the question that bothered British statesmen. Their answers, presented at the creation of the Versailles system, are of interest to us here.

${ }^{6}$ See M. Egremont, A Life of Arthur James Balfour, London, 1980, pp. 250-251; see also J. Tomes, Balfour and Foreign Policy: The International Thought of a Conservative Statesman, Cambridge, 1997.

7 See, for example, T. Komarnicki, Rebirth of the Polish Republic: A Study in the Diplomatic History of Europe, 1914-1920, London, 1957, pp. 141-222; W. Sukiennicki, East Central Europe during World War I: From Foreign Domination to National Independence, ed. M. Siekierski, vol. 2, New York and Boulder, 1984; Wilsonian East Central Europe: Current Perspectives, ed. J.S. Micgiel, New York, 1995. 
The new government, with a Conservative majority, but still with the Liberal David Lloyd George at the helm, was responsible for preparing the right solutions. Lloyd George contemplated, critically at first, an option presented to him by Jan Smuts, the South African member of the Imperial War Cabinet. Smuts wanted to restore full cooperation with Germany as the best way to recreate stability and peace on the Continent. And with independent Poland reaching out for the Prussian part of Germany's territories (Gdańsk/Danzig, Upper Silesia, the Poznań region), he deemed such a cooperation with Berlin impossible. So his opinion was clear: if any geopolitical changes would be introduced in Eastern Europe, they were to conform to the will of Germans (and Russians, for that matter), and not the "lesser" and "incapable" other peoples that happen to live in-between. In his memorandum addressed to Lloyd George on 22 May 1919, Smuts actually reiterated some of the Balfour memo's arguments: "The new Poland will include [...] territories which have for very long periods been part of Germany (or Russia). It is reasonably certain that both Germany and Russia will again be great Powers, and that, sandwiched between them, the new Poland could only be a success with their good will. How, under these circumstances, can we expect Poland to be other than a failure, if she had that ruling and administrative capacity which history has proved she has not? [...] I think we are building a house of sand". ${ }^{8}$ The South African statesman who had never been to Poland, but sympathized with the fate of downtrodden Germany, had no misgivings presenting such a straightforward opinion on Poles in general: "Kaffirs, that's what they are!". 9 In his opinion, "civilized" Germans were the only natural partners to recreate a civilized order in Eastern Europe, and not those natural born slaves, or half-children at best, who lived to the east and south of them.

On the day he received Smuts' letter of protest Lloyd George read it aloud to President Wilson and Georges Clemenceau it. Even though the British prime minister objected at first ${ }^{10}$ to the suggestions of the South African, he actually followed his reasoning. Not in the racist opinions on Poles perhaps, neither in Smuts' philo-Germanic attitude, typical for a majority of the imperial educated class in its reverence for German achievements in the arts and sciences (combined with a more or less complete ignorance of other people living between the Oder, the Dnieper and the Danube). No, just like his foreign secretary Arthur Balfour, the Prime Minister did not want to fix his mind "on the lamentations of the Germans

8 J. Smuts, “Germany's Eastern Frontier” [addressed to Lloyd George, 22 May 1919], in: Selection from the Smuts Papers, vol. 4: November 1918-August 1919, eds. W.K. Hancock, J. van der Poel, Cambridge University Press, 1966, pp. 185-186.

9 Smuts said this in his conversation with the Chancellor of the Exchequer, Austen Chamberlain, in July 1919, see: The Austen Chamberlain Diary Letters. The Correspondence of Sir Austen Chamberlain with his Sisters Hilda and Ida, 1916-1937, ed. R.C. Self, Cambridge, 1995, p. 116.

10 See Lloyd George's letter to Smuts, 3 June 1919, in: Selection from the Smuts Papers, vol. 4, pp. 217-218. 
and their misfortunes". He was a more pragmatic carrier of this first appeasement, as Antony Lentin calls the phenomenon of a pro-German revisionism among British (and American) political elites during the peace conference in Paris. ${ }^{11}$

Lloyd George believed in order based on an agreement with its responsible guardians: that is to say with traditional imperial partners, not just France and Italy, but Germany and Russia as well - in their "natural" sphere of responsibility in Eastern Europe. Unlike the conservative Balfour, the liberal-minded Lloyd George was ready to accept even the new ("Red") Russia in this traditional, geopolitical role. He had already tried to enter a political dialogue with the Bolsheviks at the beginning of 1919 - with his so called "Prinkipo Islands" conference initiative. ${ }^{12}$ Then he had to allow his government's conservative majority (backed by France) to try a more interventionist policy, but finally, at the end of 1919 and the collapse of the main anti-Bolshevik forces in Russia, he forced his colleagues in the Cabinet to accept the idea of "peace through trade". It aimed at the peace with Bolshevik Russia based on economic reasons and faith in progress and stability. The fundamentals of these more optimistic ideas were exactly the same as in the more melancholic view of Balfour: Russia (any Russia, now the "Red" one) and Germany are the most important, or rather the only important partners for the economic renewal of the Continent and peace. Lloyd George intended to "fight anarchy with abundance". ${ }^{13}$

He wanted to appease Germany - with his decision, imposed in Versailles, of denying Danzig to Poland, and leaving the question of Silesia open to the future decision of plebiscites - in order to bring her delegation to London, firstly for economic talks, then for political talks. When the Polish foreign minister, Stanisław Patek, presented on 26 January 1920 his government's concerns with the possibility of a Bolshevik offensive towards the German centre of Europe overrunning Poland and other "minor" countries on the way, Lloyd George answered in a very characteristic manner. He tried to persuade Patek, as well as his conservative colleagues in the Cabinet "that there were not sufficient foodstuffs or raw materials in Poland, Hungary, or Germany to attract an invasion by the Red Army". All these countries, he said, "could offer nothing to the Bolshevik armies but famine and typhus". ${ }^{14}$ This is revealing both in its stress on economics as the only important lever in political developments (combined with a complete disregard for ideology

11 A. Lentin, Lloyd George and the Lost Peace: From Versailles to Hitler, 1919-1940, New York, 2001, pp. 67-88.

12 See, for example, J.M. Thompson, Russia, Bolshevism, and the Versailles Peace, Princeton (NJ), 1966, pp. 82-129; R. Ullman, Anglo-Soviet Relations, 1917-1921, vol. 2: Britain and the Russian Civil War, Princeton (NJ), 1968; R.K. Debo, Survival and Consolidation: The Foreign Policy of Soviet Russia, 1918-1921, Montreal and Kingston, 1992, pp. 36-39.

13 See: M.G. Fry, And Fortune Fled. David Lloyd George, the First Democratic Statesman, 1916-1922, New York, pp. 418-423.

14 Quoted after Richard H. Ullman, Anglo-Soviet Relations, 1917-1921, vol. 3: The Anglo-Soviet Accord, Princeton (NJ), 1972, p. 25. 
and geopolitics), and in its attitude towards all countries between Russia and Germany. These countries have nothing to offer - not just to the Bolsheviks, but (even more so) - to the Western powers, to the British position and prosperity. They were dispensable, unlike Russia, even Bolshevik Russia, which supposedly had great deposits of grain, so desperately needed in the rest of Europe. ${ }^{15}$

I will not dwell here on Lloyd George's policy towards Poland and Bolshevik Russia in 1920, as I have just published an extensive book on this subject. ${ }^{16}$ I only want to stress that both Balfour in his conservative-geopolitical way, and Lloyd George in his liberal-economic perspective saw Eastern Europe on their mental maps exactly as a borderland (a "thin" one, not to provoke the anger of its more powerful and "meaningful" neighbours) between Germany and Russia. They both believed in an order which should be based on these two empires, at least in Eastern Europe, beyond the pale of British imperial interests.

The Labour Party, backed by the trade union movement, a very active and vociferous minority power in British politics after the December 1918 elections, presented another set of arguments for leaving Eastern Europe to Russia rather than to bothering with "lesser" nations inhabiting those "far-away countries". They sympathized with the cause of the Revolution, and felt the cause of social progress was represented by the Bolsheviks rather than by any of their enemies in Eastern Europe - the Russian "Whites" or national "bourgeois" governments created from the ruins of the Romanovs' empire. "Poland had sinned against humanity's best hope" is how the Daily Herald summed up this attitude. The newspaper would express the voice of the left-wing opposition (so called Councils of Action) to any British help given to Poland after it was invaded by the Red Army in July and August 1920. Poland, fighting with Bolshevik Russia, would be seen not as the weaker state defending its independence against its former imperial overlords, but as a reactionary force which tried to stop the inevitable development of the first socialist state in the world. The Labour Party used exactly the same words as the Herald to describe their political stand at the moment when the Red Army was at the gates of Warsaw, at the very centre of ethnographic Poland. To help "reactionary" Poland at such a moment, it declared, would have been be "an intolerable crime against humanity". ${ }^{17}$

15 This assumption, totally absurd, given the unprecedented famine in Russia under the Bolsheviks at that particular moment, was infused by the chief economic advisor to Lloyd George, Edward F. Wise, in his memorandum: Economic Aspects of British Policy Concerning Russia (from January 1920), see Ullman, Anglo-Soviet Relations, 1917-1921, vol. 3, pp. 14-18.

16 A. Nowak, Pierwsza zdrada Zachodu. 1920: zapomniany appeasement, Kraków, 2015.

17 E.M. Carroll, Soviet Communism and Western Opinion 1919-1921, Chapel Hill (NC), 1965, pp. 167-170; S. White, "Labour's Council of Action 1920", Journal of Contemporary History, 9, 1974, pp. 99-122 (quotation at p. 102); P. White, Iron Curtain. From Stage to Cold War, Oxford, 2007, pp. 137-139; N. Davies, White Eagle, Red Star. The Polish-Soviet War, 1919-1920, London, 1983, pp. 177-181. 
I do not intend to present here details of the "Hands off Russia!" agitation and the subsequent pro-Bolshevik strikes led by the Council of Action and the demonstrations throughout England in the summer of 1920. I just want to add one general remark: the British left wing paradoxically shared the Order-Chaos model of interpreting geopolitical shifts in Eastern Europe, at least after the Russian revolutions of 1917. Russia represented the force of Order (however brutal it might be): the new Order, or - to put it simply - the New World. Minor states on its western borderlands, on the way to "Europe" (which for the British left, just like for the British conservatives or liberals, ended in the East on the imagined borders of Germany), belonged to the forces of the Old, the forces of Chaos. They did not represent any interesting social experiment worthy of compassion. New humanity had new hope in Russia, and whoever stopped this hope to change the grim postwar continent into a land of a socialist promise was a "sinner". The leader of the Council of Action, Ernest Bevin, could only agree with this part of the Balfour statement: "The more Russia is made a European rather than an Asiatic Power, the better for everybody". ${ }^{18}$ The "big picture", the "great vision" - also for those believing in progress - tended to obscure lesser "dots" that did not fit in, and had just found, or were still fighting, to their place on the political map of Europe.

Winston Churchill, War Secretary, saw it otherwise. His anti-Bolshevik attitude as well as his futile efforts to help the "Whites" to win the Russian Civil War are analysed in so many books and articles that I do not need to dwell upon this subject. I would rather like to note that his perception of Eastern Europe was actually the opposite of that of the leftist sympathizers of the Bolsheviks. Churchill saw Russia and Eastern Europe as the battlefront between Order and Chaos, too. The difference was that the Bolsheviks were to him the epitome of universal Chaos, and anything opposing them was identified as an ally of Order. He believed that the main forces deciding the outcome of this dramatic confrontation were Russia and Germany. In his memorandum of 19 September 1919, he warned dramatically about the possibility of their collaboration, either in a combination of "Red" Russia with "Red" Germany, or "Black" (reactionary, monarchist) Russia with "Black" Germany, or even "Red" Russia with "Black" (reactionary and revanchist) Germany. Such a collaboration could be joined by Japan, and thereby outweigh Britain, France, and the United States. Churchill used this warning as an argument to help the "White" Russian forces under Denikin, and was ready to appeal to his own government to use Germany against Russia, if necessary. What is especially interesting to us here is that he began to acknowledge the fact that there were also other players in this vital, Eastern European showdown. He saw them as minor players, but players nonetheless: Poland, three new Baltic republics, and even "feeble Ukrainian forces under Petlyura". They all were able to influence the outcome of the decisive

18 See L.J. MacFarlane, "Hands Off Russia: British Labour and the Russo-Polish War, 1920", Past \& Present, 38, 1967, pp. 126-152; Nowak, Pierwsza zdrada, pp. 355-376. 
confrontation. Churchill drew a conclusion form this observation: these minor players should be acknowledged in London, and taken into strategic consideration.

For Ukraine, he had "the conception of a Russia consisting of a number of autonomous States, grouped together on a federal basis into a Russian union". Such a union, he felt, "is one within which all legitimate aspirations may be comprised. The new Russian state, reformed along these lines, would be less a menace to the future peace of the world than the vast centralized empire of Czarism" ${ }^{19}$ For the Baltic states, Churchill wanted their full recognition by the Allies in return for an undertaking by them to attack the Bolsheviks (to help the "Whites"). Lloyd George responded to these proposals in a very characteristic way: "Whether the Bolsheviks or the anti-Bolsheviks get the upper hand, they would not recognize the independence of these [Baltic] States as it would involve the permanent exclusion of Russia from the Baltic. Would you be prepared to make war with an Anti-Bolshevik regime if they attempted to reconquer these States and to secure the old Russian ports of Riga and Reval?". ${ }^{20}$ The Prime Minister did not even bother to comment on Ukraine, as he considered it to be evidently a Russian internal matter. We have to stress it again: for Lloyd George Russia, any Russia, was the natural, and only important partner for London to keep order in Eastern Europe. That is why he wanted to satisfy Russian demands in the region as fully as possible - just to the borders of Germany, another pillar of European order. For Churchill, Bolshevik Russia was not such a partner - and that is why he was ready to undermine her with "minor forces" in Eastern Europe. And he had one potential ally in the government: the new Foreign Secretary (acting since January 1919, and officially since October of that year), George Nathaniel Curzon.

Lord Curzon was personally very much interested in Russia, but from a very particular perspective. As a young aristocrat he had been a successful explorer of the geopolitical shift between the Russian and British Empires. He understood Russia from the perspective of the Great Game of empires in Asia, from Afghanistan and Persia - studied by him as outposts of British interests threatened by the Romanovs' imperial designs. For him Russia - any Russia - was the enemy, but his conservatism made compromises with Red Russia even harder to swallow. Even though he failed to assert himself as the principal architect of British foreign policy, being dominated (like everyone else in the Cabinet) by Lloyd George, Curzon tried to influence the "Russian" policy of his government towards a "realistic" Friend-Foe model, based on an assessment of the conflicting interests of two rival empires. He intended to push back Russia from the Caucasus (Azerbaijan and Georgia) and the Caspian Sea, to diminish the Russian imperial threat which he

19 W. Churchill, "Russian Policy”, 19 September 1919, Parliamentary Archives (London), Lloyd George Papers - LG/F/202/10-11.

${ }^{20}$ Lloyd George to Churchill, 22 September 1919, quoted after: M. Gilbert, World In Torment: Winston S. Churchill 1917-1922, London, 1990 (1st ed. 1975), p. 333. 
considered most important to British imperial power in Asia. ${ }^{21}$ From that particular perspective Curzon was ready to take the new states organized on the ruins of the former Romanov Empire as useful tools in the British imperial game against its strategic foe. Because they were placed in the area he believed counted in that strategic game, he believed they should be taken into consideration by London statesmen, and not just left for Russia and Germany.

It was Curzon who introduced to the government probably the single most interesting document confirming such an unusual perspective on Eastern Europe. He did so exactly at the moment he became the official head of the Foreign Office. The document passed unnoticed by students of British foreign policy of the time, but it is really worth noting here. Dated 3 October 1919, it was introduced by Curzon as a proposed answer to the question raised by the Prime Minister "at a recent meeting of the War Cabinet". The question was "whether British interests in particular and the peace of the world in general would be better served by a revived and united Russia, or by the reverse". The answer was prepared, as Curzon stated, "by an able member of the Foreign Office staff", most likely John Duncan Gregory. ${ }^{22}$ This secret, nine-page memorandum, circulated among the members of the Cabinet, began with a suggestion that had the "old" Russia (represented by "Sazonoffs" and "Denikins") been re-established, that would have rather provoked further conflicts than brought stability. In that case there would be no independence for Finland, no question of making any concessions to the Baltic States, which would gain autonomy at best, controversy with Poland, and, finally, "the ambitions [of Russia] and the competition of the latter in the Caucasus and in Persia will be revived". All that would have led to another geopolitical upheaval in Eastern Europe and made the spectre of Russo-German collaboration materialize again, resulting in "the massacre of the smaller States". This would, stressed the author, be akin to the eighteenth-century collaboration of Russia and Germany. Besides, Russia "run on old lines" would have carried the seeds of another revolution.

The memorandum acknowledged the fact that a weak Russia also offered possible dangers to be taken into strategic account: such as "every sort of political and commercial penetration from Germany in the West and from Japan in the East", and anarchy in Central and Western Asia, which would bring the whole burden of maintaining order in the region on the British Empire. The author suggests that the answer to what sort of Russia would be best for the interest of the

${ }^{21}$ See D. Gilmour, Curzon: Imperial Statesman, New York: Farrar, Strauss \& Giroux, 1994; G.H. Bennett, British Foreign Policy During the Curzon Period, 1919-1924, New York, 1995, pp. 41-75; M. Hughes, British Foreign Secretaries in an Uncertain World, 1919-1939, New York, 2006, pp. 17-32; S. Kelly, "How Far the West?: Lord Curzon’s Transcaucastian (Mis)Adventure and the Defence of British India, 1918-23", International History Review, 35, 2013, pp. 274-293.

22 "Secret. Printed for the War Cabinet", 3 October 1919, Parliamentary Archives (London), Lloyd George Papers - LG/F/202/1/12. See also J.D. Gregory, On the Edge of Diplomacy: Rambles and Reflections, 1902-1928, London, 1929; Nowak, Pierwsza zdrada, pp. 297-302. 
United Kingdom was to be found in the region of the former Polish-Lithuanian Commonwealth: "Poland is the pivot on which our Eastern European policy ought to turn". ${ }^{23}$

A political-strategic collaboration between Poland, the three new Baltic States (Lithuania, Latvia, Estonia), and Finland would have been crucial. Churchill advanced the concept of using these countries as bases for a concerted anti-Bolshevik action whose goal was the restoration of "White" Russia. The author of the memorandum questioned the wisdom of this politics: "it is very doubtful whether Poland would consider it to her interest to put a forcible end to the Bolshevik regime since she would have little choice but to hand over a liberated Russia to the tender mercies of Denikin, with untoward consequences to herself". The actual policy pursued by the British government as whole, that is to leave Eastern Europe to work out its own salvation, would lead to a series of separate peace treaties between Poland, the Baltic States and other "Border States" (as the new states between Russia and Germany were called in Paris in 1919) and Bolshevik Russia. Such peace treaties would have only strengthened the Bolsheviks and given no permanent stability to the Border States, opening their societies to the influences of Soviet propaganda and further revolution. So neither of these options was advocated in the memorandum. Instead, it presented a third option. This was based on the assumption that collaboration between the "non-Bolshevist Russians" and the "Border States", with Poland as the key among them, was possible and should be encouraged by the British government. Such collaboration would have not been aimed at restoration of the one and indivisible Russian Empire (so vitally dangerous to the new border states), but would have been based on reality of this choice: "a future Russia dependent on the goodwill of even its smallest neighbours or no future Russia at all". The author added a special argument to his suggestion that the British government should have really changed his priorities in Eastern Europe: "Poland and Finland are Western countries with all the traditions and education of European civilization [...] The lesser Border States are equally Western. But the Russians, Bolsheviks and non-Bolsheviks alike, are manifesting every day more the characteristics of unstable orientalism, and have still to prove that, without the German stuffing of centuries they are capable at self-government" ${ }^{24}$

As a possible solution to the Russian question the memorandum proposed "the confederation idea", which meant that "we should progressively recognize the virtual independence or provisional independence, or extreme autonomy of self-governing communities in Siberia, the Ukraine, White Russia, and anywhere else where Bolsheviks may recede." Developing this unique perspective, the

23 This and other quotations in the paragraphs above are from the untitled memorandum circulated by Curzon: "Secret. Printed for the War Cabinet", 3 October, 1919, Parliamentary Archives (London), Lloyd George Papers - LG/F/202/1/12.

24 Ibid., p. 6. 
memorandum's author reflected upon Ukraine and Belarus ("White Russia") as "candidates" for independence. Ukraine was in her relation to Russia compared to the relation between Austria and Germany. However it could be considered "an artificial state", the author stated boldly that "there would be no violent infraction of modern political principles in creating it", and added that it could survive either in a federation or in an alliance with Poland. Even though "White Russia" had expressed "even less" separatist tendencies than Ukraine, it could also form an independent state. Siberia, due to its geographical position and economic resources was considered to be "more naturally formed as a separate state".

After presenting this scenario of actual dismemberment of the Russian Empire, the "able member of the Foreign Office staff", in the words of Lord Curzon, supported it with his opinion that "in Russia there is no such thing as patriotism in the accepted Western sense of the word" and that even the "old Orthodox religion" would not be strong enough to hold the disintegrating body of the empire together. The author, therefore, persuasively presented the above scenario as possible. But was it "to our interest"? The question posed in the memorandum is introduced with two assumptions. Firstly, the necessity of preventing Russia from becoming a German colony or of allowing "a German-Japanese-Russian combination" that would push the British Empire out of Eurasia from coalescing; and secondly, the necessity "to secure our Eastern frontiers against anarchy". The best means to exclude the first danger was to strengthen Poland (as a barrier between German influences and Russia), possibly confederated with Lithuania and even with Ukraine. The problem of anarchy would not be solved by the reestablishment of the Russian Empire: "Centralisation of Government in a country is always dangerous to its neighbours, and Russia cannot get on without a dictatorship". A system of separate states could be fragile and insufficient to keep out the danger of anarchy in Eastern Europe. But once it was backed by Western industrial and political influence - it could work. The author sums up his considerations clearly:

We have to make up our minds to a new course of action. It is then that the question of embarking on a real political stake in Poland and the border states comes up for consideration. The alternatives are either to make peace with the Bolsheviks, to retire definitely from the fray, or to attempt a combination of Poland and the border states. The first is problematical, if not a definite surrender to an enemy, probably greater than Prussianism, and the second is to abandon the whole of Eastern Europe to Germany. The third, therefore, is the only one that offers any chance of success. But it should clearly carry with it our right to restrain the States with whom we act from encroaching beyond their due limits and to direct them to relations with a reconstructed Russia. ${ }^{25}$

The actual course taken by the British government at the end of 1919 would be a combination of the first (peace and even a geo-economic accord with Bolshevik

25 Ibid., p. 8. 
Russia - the true goal of Lloyd George) and the second options (in case the first one was unsuccessful). The third option, and the only one which took the strategic meaning of the "border states" seriously, was very quickly rejected. The "Whites" lost their chance in the Russian Civil war, if they ever had one. The British Cabinet decided on 29 January 1920, that "the border states" surrounding Russia must themselves take the full responsibility for deciding between peace and war. This actually meant full responsibility for deciding between capitulation and defence in case of a Bolshevik offensive - and no engagement from London in either case. ${ }^{26}$

The decision of the Cabinet was taken exactly after hearing the most outspoken proponent of the ideas presented four months earlier in the memorandum of 3 October. This rare occasion of explaining his views to members of the government was given on 29 January 1920 to no one else but Sir Halford Mackinder. The father of geopolitics, the author of the most famous treatise on the subject - Democratic Ideals and Reality, published in 1919 with the (futile) intention to inspire statesmen in Versailles - engaged himself in an effort to bring the idea of forming a stable coalition of "Border States" into reality. ${ }^{27}$ He accepted the mission offered to him by Lord Curzon on 23 October 1919 to be a special envoy to General Denikin, leader of the anti-Bolshevik army in South Russia, to Poland, and to other "Border States" (Romania and Bulgaria). The goal of the mission was to try to organize an effective military and political alliance between the last forces of anti-Bolshevik Russia and these states in order to tame the imperial ambitions of the Bolsheviks and to create a new geopolitical system of stability in the region and in all Europe. The Oxford geographer (since 1910 a Conservative and Unionist Member of Parliament), spent several exciting weeks on his Eastern European tour between early December 1919 and mid-January 1920. He visited the Polish Head of State, Józef Piłsudski in Warsaw, where he found full support for his mission. Then he moved to Bucharest and Sofia, where he met with less success. Finally he met General Denikin, already beaten by the Bolsheviks and due to this desperate position more inclined to the idea of strategic cooperation with Poland, the new Caucasus border states, and other "lesser neighbours" of Russia. When Mackinder came back to London, he was determined to persuade his government to adopt the new policy in Eastern Europe: to "range up all the anti-Bolshevist States, from Finland to the Caucasus" and to give them "a certain amount" of political and military support. Mackinder's position was concluded for the Cabinet meeting on January 29 with the following opinion: "It was necessary to adopt the whole policy or to do nothing. The alternative was to see the Bolsheviks come down to the

26 See The Churchill Documents, ed. M. Gilbert, vol. 9: Disruption and Chaos, July 1919 - March 1921, Hillsdale (MI), 1977, p. 1020 (Cabinet minutes, 29 January 1920); Gilbert, World in Torment, pp. 320-64; Fry, And Fortune Fled, pp. 413-418; Ullman, Anglo-Soviet Relations, vol. 2, pp. 294-304.

27 See B. Blouet, Halford Mackinder: A Biography, Austin (TX), 1987; G. Kearns, Geopolitics and Empire: The Legacy of Halford Mackinder, Oxford, 2009. 
Black Sea, to the Crimea and to Odessa, which would be a complete moral victory for them. It would be necessary to drive his policy to extremes. Once an alliance such as he contemplated had been created, and the morale of the anti-Bolshevist States had been re-established, we should be in a much better position to obtain a Peace with a Soviet Russia which was not triumphant" ${ }^{28}$

The mission itself is not the focus of our interest. ${ }^{29}$ What is interesting here is a geopolitical perspective offered by Halford Mackinder not just in his - unsuccessful - attempt at persuasion addressed to the Cabinet at the end of January 1920, but also earlier, and in a more developed way, in his book. Democratic Ideals and Reality was actually the most sophisticated proposal of changes in British (and, one can say more generally: Western) perspectives on Eastern Europe. Probably it is this book which had inspired the way of thinking and preparing arguments in the anonymous memorandum circulated by Curzon in early October 1919. It was not effective enough to change the perceptions of such people as Arthur Balfour or David Lloyd George, but it left its political testament which influences further reflections. So, to conclude this exploration of the British imperial imagination and the place Eastern Europe occupied in its different variants during and after the Great War, I would like to present the arguments introduced by Halford Mackinder.

Mackinder, born in 1861 (two years older than Lloyd George, and two years younger than Curzon), educated at Oxford and appointed the first Reader in Geography there in 1887, one of the founders and the first director of the London School of Economics, pronounced his main geopolitical ideas in 1904. On 25 January 25 year he gave a lecture on "The geographical pivot of history" at the Royal Geographical Society. He proposed a formula of "geographical causation in universal history". After 400 years of the Columban epoch, geographical exploration was over and the world for the first time formed a "closed political system". This was the warning he addressed towards the British attitude of splendid isolation. Isolation was not possible any more. "Every explosion of social forces, instead of being dissipated in a surrounding circuit of unknown space and barbaric chaos, will be sharply re-echoed from the far side of the globe, and weak elements in the political and economic organism of the world will be shattered in consequence". ${ }^{30}$ Mackinder's diagnosis signified that there would be no "faraway countries of which

28 "Notes of points, supplementary to his memorandum of January 21, 1920, made by Sir H.J. Mackinder in reply to questions put to him at the Cabinet Meeting held on Thursday, January 29, 1920, at 11-30 a.m.", National Archives (Kew), Foreign Office 800/251 ("Private Papers of Sir H.J. Mackinder, Relating to His Mission to South Russia, October 1919 to February 1920”), p. 7.

${ }^{29}$ For more details of the mission see Documents on British Foreign Policy, first series, vol. 3, eds. E.L. Woodward, R. Butler, London, 1949, pp. 672-78 (Curzon's instruction for Mackinder, 2 December 1919), pp. 768-86 (Mackinder's report), pp. 792-93 (Denikin’s letter to Mackinder, 14 January 1920); see also A. Nowak, Polska i trzy Rosje. Studium polityki wschodniej Józefa Piłsudskiego (do kwietnia 1920 roku), 3rd ed., Kraków, 2015, pp. 389-410.

${ }^{30}$ H.J. Mackinder, “The Geographical Pivot of History”, Geographical Journal, 23, April 1904, 4, p. 421. 
we know nothing" (as Neville Chamberlain would describe Czechoslovakia at the time of the Munich conference thirty-four years later). A responsible statesman should look around the globe in this new situation and find the places of potential crisis as well as those points on the map that would be crucial to any serious effort to avert crises.

The most important of these places was pointed out by Mackinder himself. $\mathrm{He}$ spotted it as a consequence of his geohistorical observation that Asia and Europe actually form one great continent, and "European civilization is, in a very real sense, the outcome of the secular struggle against Asiatic invasion". The struggle is not over. Russia has managed through her centuries-long expansion to occupy the most important strategic position on this vast Euro-Asian continent, the heart-land, as Mackinder called it for the first time. "To east, south, and west of this heart-land are marginal regions, ranged in a vast crescent, accessible to shipmen". ${ }^{31}$ The British Empire took control over the key positions of this crescent. This enabled London to contain the danger of the "heart-land" empire's domination over the whole of Eurasia. Land power versus sea power, camel and horse versus naval vessels, now - the Trans-Siberian railway versus the Suez Canal. Such was the epitome of the Friend-Foe model comprised in the first sketch of Mackinder's geopolitics. He saw Russia as the major threat, as well as a possibility of Russian-German alliance. Russia, through her further expansion "over the marginal lands of Euro-Asia", especially if allied with Germany, would be able to overset the balance of power in favour of herself - "and the empire of the world would then be in sight". ${ }^{32}$

Mackinder did not see any role for the Eastern European prey of Russian imperial expansion in his 1904 geopolitical "manifesto", though he enumerated them in a historical overview: from Finland, through the old Polish-Lithuanian Commonwealth, all the way to Turkey. He tried to focus the attention of his listeners on the necessity of collaboration between other crescent (sea) powers - France and Italy - with two Anglo-Saxon empires. To keep the Eurasiatic crescent - from Sweden to the Mediterranean, Egypt, Turkey, Persia, India, up to Korea - out of future Russian (or Russian-German) incursions: this was his geostrategic "recipe" of 1904. ${ }^{33}$

But once he identified geographically the enemy (or even a more deadly combination of two enemies), he would be able to develop his "recipe", adding important new ingredients to it. The ingredients - that is potential friends against enemies - were to be found, re-created, and strengthened on the geopolitical shift in Eastern Europe. We can trace the beginnings of Mackinder's interest in the region to 1905, when he published the English translation of Joseph Partsch's

31 For the quotations: ibid., pp. 422 and 431.

32 Ibid., p. 436.

${ }^{33}$ For contemporary interpretations of this path-breaking text and its immediate political contexts, see G. Kearns, “The Political Pivot of Geography”, Geographical Journal, 170, 2004, 4, pp. 337346; P. Venier, "The Geographical Pivot of History and Early Twentieth-Century Geopolitical Culture", Geographical Journal, 170, 2004, 4, pp. 330-336. 
treatise on Central Europe. It presented - for the first time so distinctly - a danger of German Mitteleuropa: a not so distant future dream of Friedrich Naumann and the brief reality of the Treaty of Brest-Litovsk. During the Great War, the British geographer turned back-bench MP and political commentator deepened his interest in nationalities of the region between Russia and Germany. He tried to find resources there to counter the German Mitteleuropa project, and - at the same time - not to open the region to further Russian expansion. He was even elected as a delegate of the Serbian Society to the Congress of Oppressed Nationalities in Rome of 1918. ${ }^{34}$

Immediately after the war he decided to voice his concerns in Parliament for the benefit of the authors of the new, post-war order. He wanted to warn democracies that if they intended to realize their ideal of the League of Nations they had to "recognise these geographical realities" that lend themselves to the growth of empires, and in the end of a single world empire. "Can we establish such a world power as shall suffice to keep the law between great and small states, and yet shall not grow into a world tyranny? There are two roads to such a tyranny, the one the conquest of all other nations by one nation, the other the perversion of the very international power itself which may be set up to coerce the lawless nation". ${ }^{35}$ How to avoid both pitfalls? "What degree of international reconstruction is necessary if the world is long to remain a safe place for democracies. [...] Shall we succeed in soberly marrying our new idealism to reality?". ${ }^{36}$

The answer given by Mackinder extolled the meaning of the geographical divides he had spotted already in his "pivot" article. Germany and Russia would not become instantly or even quickly pillars of a democratic world order. They are too much "tempted" by their history and geography to try again to rule over the continent - not just Europe, but "the joint continent of Europe, Asia, and Africa", the whole "World-Island", as he called it for the first time in the book. Russia occupies the Heartland, Germany is in the centre of Europe. The key region is the one between them: it decides who can aspire to the domination of the World-Island. The region is Eastern Europe. Here Mackinder formulated his famous saying: "Who rules East Europe commands the Heartland; who rules the Heartland commands the World-Island; who rules the World-Island commands the World". ${ }^{37}$

34 See Mackinder's articles published at this time: “Adriatic Question”, Glasgow Herald, 3 December 1917; "The New Map of Europe”, Glasgow Herald, 8 May 1918; "Rome Conference”, Glasgow Herald, 20 May 1918; "End of Empire: The Break-up of Austria-Hungary", Glasgow Herald, 31 October 1918. For more details of Mackinder's developing interest in Eastern European problems, see S. Pelizza, "Geopolitics, Federalism, and Imperial Defence: Halford Mackinder and Eastern Europe, 1919-1920", available at https://www.academia.edu/4708068/Geopolitics_ Federalism_and_Imperial_Defence_Halford_Mackinder_and_Eastern_Europe_1919-20 (accessed: 8 January 2016).

${ }^{35}$ H.J. Mackinder, Democratic Ideals and Reality, London, 1919, p. 5.

36 Ibid., p. 8.

37 Ibid., p. 194. 
Victorious Western democracies should concentrate their efforts on reconstructing the international order and not just on the idealistic premises of the League of Nations, nor on futile hopes of bringing Russia or Germany into the post-war order based only on their goodwill or their interests. It was necessary to make these two vanquished powers' dreams of imperial revenge unrealizable. "The condition of stability in the territorial rearrangement of East Europe is that the division should be into three and not into two state-systems. It is a vital necessity that there should be a tier of independent states between Germany and Russia". ${ }^{38}$ Mackinder enumerates seven non-German peoples between the Baltic and the Mediterranean, "each on the scale of a European State of the second rank": the Poles, the Bohemians (Czechs and Slovaks), the Hungarians, the South Slavs (Serbians, Croatians, and Slovenes), the Rumanians, the Bulgarians, and the Greeks. On the map drawn on the following page (207) he added - somehow vaguely two Baltic states: Lithuania and Estonia (Latvia disappeared mysteriously between them). Poland exists on this map within borders close to the final demarcation of the Riga treaty from 1921.

Mackinder stressed the importance of Poland as the most numerous among these peoples, and the most strategic in its position. It was the buffer between Germany and Russia that must be completed - he insisted. The geographer proposed even a specific solution to the key territorial problem arising from the Polish accession to the Baltic, which left East Prussia detached from the rest of Germany and made it a sore point on the new map of Eastern Europe. Mackinder suggested simply "an exchange of peoples" between Prussia and - as he randomly chose - the westernmost Polish province of Posen (the official Prussian-German name for the province centred on the city of Poznan in historic Greater Poland - Wielkopolska). He concluded his geopolitical advice to the Western statesmen in Paris with the following passage:

The most important point of strategical significance in regard to these Middle States of East Europe is that the most civilized of them, Poland and Bohemia, lie in the North, in the position most exposed to Prussian aggression. Securely independent the Polish and Bohemian nations cannot be unless as the apex of a broad wedge of independence, extending from the Adriatic and Black Seas to the Baltic; but seven independent States, with a total of more than sixty million people, traversed by railways linking them securely with one another, and having access through the Adriatic, Black, and Baltic Seas with the Ocean, will together effectively balance the Germans of Prussia and Austria, and nothing less will suffice for that purpose. ${ }^{39}$

Nothing less, but something more would have been even more desirable. Mackinder suggested that both Russia and Prussia (both blocked by the solid

38 Ibid., p. 205.

39 Ibid., p. 215. 
"middle tier" in their possibilities to develop imperialistic plans) would themselves disintegrate into a number of states "in some sort of loose federation". ${ }^{40}$ The anonymous author from the Foreign Office, writing his memorandum for Curzon a few months later, would feel free to expand exactly on this subject, adding new possible candidates for "the Middle Tier": all three Baltic States, but also Ukraine and "White Russia" (meaning Belarus). And Mackinder himself tried, as we have seen, to realize this project in his mission to Piłsudski and Denikin. And he failed.

Such a geopolitical reorganization of Eastern Europe as he promoted as necessary to complement the organization of the League of Nations, adding balance to ideals, ${ }^{41}$ would not happen. Instead, a logic of appeasement would triumph. That logic was popular, because it offered a short-cut way for anti-war sentiments which dominated, quite naturally, in British society after the First World War. It was easier and less risky in terms of day-to-day politics to believe that the defeated powers that had been "responsible" for order in Eastern Europe would be satisfied enough to keep this order again, and not to engage British (or Western in general) imagination and real forces in forming a new order with new, unknown partners from the Eastern European "middle tier". As Philip Kerr, the private secretary and the real top-advisor to Lloyd George, wrote to his prime minister in September 1920: "I am very much afraid that the European situation is now unmanageable [...]. Eastern Europe is already out of control [...]. On the other hand the burden on Great Britain is now so great, in Ireland, in Egypt, in Mesopotamia, in India, and in the Labour world at home, that no government can give the time necessary to the management of European affairs. [...] You should make it clear to France and to Italy that Great Britain is not going to take on the role of Atlas". ${ }^{42}$ That role was to be given - as regards the Eastern European part of the sky - to Germany and to Russia, again. The rest was considered chaos. And so it would remain.

The sky fell in 1939.

\section{Bibliography}

\section{Sources}

Documents on British Foreign Policy, first series, vol. 3, ed. E.L. Woodward, R. Butler, London, 1949.

The Austen Chamberlain Diary Letters. The Correspondence of Sir Austen Chamberlain with his Sisters Hilda and Ida, 1916-1937, ed. R.C. Self, Cambridge, 1995.

40 Ibid., p. 223.

${ }^{41}$ L.M. Ashworth, "Realism and the Spirit of 1919: Halford Mackinder, 'Geopolitics and the Reality of the League of Nations”, European Journal of International Relations, 20, 2010, pp. 1-23.

${ }^{42}$ National Archives of Scotland (Edinburgh), Philip Kerr papers: PK, GD40/17/1280 - P. Kerr to Lloyd George, 2 September 1920. 
The Churchill Documents, ed. M. Gilbert, vol. 9: Disruption and Chaos, July 1919 - March 1921, Hillsdale (MI), 1977.

Wilsonian East Central Europe: Current Perspectives, ed. J.S. Micgiel, New York, 1995.

\section{Literature}

Ashworth L.M., "Realism and the Spirit of 1919: Halford Mackinder, Geopolitics and the Reality of the League of Nations", European Journal of International Relations, 20, 2010, pp. 1-23.

Bennett G.H., British Foreign Policy During the Curzon Period, 1919-1924, New York, 1995.

Blouet B., Halford Mackinder: A Biography, Austin (TX), 1987.

Kearns G., Geopolitics and Empire: The Legacy of Halford Mackinder, Oxford, 2009.

Carroll E.M., Soviet Communism and Western Opinion 1919-1921, Chapel Hill (NC), 1965.

Davies N., White Eagle, Red Star. The Polish-Soviet War, 1919-1920, London, 1983.

Debo R.K., Survival and Consolidation: The Foreign Policy of Soviet Russia, 1918-1921, Montreal and Kingston, 1992.

Egremont M., A Life of Arthur James Balfour, London, 1980.

Fry M.G., And Fortune Fled. David Lloyd George, the First Democratic Statesman, 1916-1922, New York, 2011.

Gilbert M., World in Torment: Winston S. Churchill 1917-1922, London, 1990 (1st ed. 1975).

Gilmour D., Curzon: Imperial Statesman, New York, 1994.

Gregory J.D., On the Edge of Diplomacy: Rambles and Reflections, 1902-1928, London, 1929.

Hughes M., British Foreign Secretaries in an Uncertain World, 1919-1939, New York, 2006.

Kearns G., "The Political Pivot of Geography”, Geographical Journal, 170, 2004, 4, pp. 337-346.

Kelly S., "How Far the West?: Lord Curzon's Transcaucastian (Mis)Adventure and the Defence of British India, 1918-23", International History Review, 35, 2013, pp. 274-93.

Komarnicki T., Rebirth of the Polish Republic: A Study in the Diplomatic History of Europe, 1914-1920, London, 1957.

Lentin A., Lloyd George and the Lost Peace: From Versailles to Hitler, 1919-1940, New York, 2001.

Lieven D., Towards the Flame. Empire, War and the End of Tsarist Russia, London, 2015.

Lloyd G.D., War Memoirs, London, vol. 1 [1933].

MacFarlane L.J., "Hands Off Russia: British Labour and the Russo-Polish War, 1920", Past \& Present, 38, 1967, pp. 126-152.

Mackinder H.J., “The Geographical Pivot of History”, Geographical Journal, 23, April 1904, 4, p. 4.

Mackinder H.J., Democratic Ideals and Reality, London, 1919.

Nowak A., History and Geopolitics: A Contest for Eastern Europe, Warsaw, 2008.

Nowak A., Pierwsza zdrada Zachodu. 1920: zapomniany appeasement, Kraków, 2015.

Nowak A., Polska i trzy Rosje. Studium polityki wschodniej Józefa Piłsudskiego (do kwietnia 1920 roku), 3rd ed., Kraków, 2015.

Pelizza S., "Geopolitics, Federalism, and Imperial Defence: Halford Mackinder and Eastern Europe, 1919-1920", https://www.academia.edu/4708068/Geopolitics_Federalism_and_ Imperial_Defence_Halford_Mackinder_and_Eastern_Europe_1919-20 (accessed: 8 January 2016).

Singh Mehta U., Liberalism and Empire. A Study in Nineteenth-Century British Liberal Thought, Chicago (IL), 1999.

Smuts J., “Germany's Eastern Frontier” [addressed to Lloyd George, 22 May 1919], in: Selection from the Smuts Papers, vol. 4, November 1918-August 1919, eds. W.K. Hancock, J. van der Poel, Cambridge University Press, 1966.

Sukiennicki W., East Central Europe during World War I: From Foreign Domination to National Independence, ed. M. Siekierski, vol. 2, New York and Boulder (CO), 1984. 
Thompson J.M. Russia, Bolshevism, and the Versailles Peace, Princeton (NJ), 1966.

Tomes J., Balfour and Foreign Policy: The International Thought of a Conservative Statesman, Cambridge, 1997.

Tunander O., "Post-Cold War Europe: A Synthesis of a Bipolar Friend-Foe Structure and a Hierarchic Cosmos-Chaos Structure?", in: Geopolitics in Post-Wall Europe, eds. O. Tunander, P. Baev, V.I. Einagel, London, 1997.

Ullman R.H., Anglo-Soviet Relations, 1917-1921, The Anglo-Soviet Accord, Princeton (NJ), 1972.

Ullman R.H., Anglo-Soviet Relations, 1917-1921, vol. 2: Britain and the Russian Civil War, Princeton (NJ), 1968.

Ullman R.H., Anglo-Soviet Relations, 1917-1921, vol. 3: The Anglo-Soviet Accord, Princeton (NJ), 1972.

Venier P., "The Geographical Pivot of History and Early Twentieth-Century Geopolitical Culture", Geographical Journal, 170, 2004, 4, pp. 330-336.

White P., Iron Curtain. From Stage to Cold War, Oxford, 2007.

White S., "Labour's Council of Action 1920", Journal of Contemporary History, 9, 1974, pp. 99-122.

Andrzej Nowak, historian, professor at the Institute of History of the Polish Academy of Sciences, Head of the Department of History of Eastern Europe at the Jagiellonian University, co-founder and editor-in-chief of ARCANA (1994-2012), since 2014 editor-in-chief of the Studies into the History of Russia and Central-Eastern Europe. His scholarly interests focus mainly on the political history and political thought of Eastern Europe in the nineteenth and twentieth centuries. Author of more than 20 books from the history of Poland and Russia. He recently published: Imperiological Studies. A Polish Perspective (2011), Strachy i Lachy. Przemiany polskiej pamięci (2012), Intelektualna historia III RP (2013), Putin: źródła imperialnej agresji (2014), Dzieje Polski, vol. 1 (2014), vol. 2 (2015), and vol. 3 (2017); Pierwsza zdrada Zachodu: zapomniany appeasement (2015). He has lectured on the history of Eastern Europe at American universities (Rice, Harvard, Columbia), English (Cambridge, London University), Canadian (University of Toronto, McGill, University of Alberta), and in Dublin, Tokyo and Brno (chlapnowak@neostrada.pl). 